\title{
COMPARATIVE STUDIES IN ORGANIC ARSENIC DERIVATIVES
}

By A. J. EWINS, D.Sc., and J. G. EVERETT, B.Sc., A.I.C.

II

In the first paper * of this series attention was drawn to a new series of organic compounds of arsenic, the benzisoxazine derivatives, which from their structural relationship both to Stovarsol (3-acetylamino 4-hydroxy-phenylarsinic acid) and to Tryparsamide (sodium salt of $\mathrm{N}$-phenyl-glycinamido- $p$-arsinic acid) promised to be of some interest. A very considerable number of compounds of this series has now been examined, and it is here proposed to place on record some of the results obtained and briefly to review them.

The compounds have been examined for toxicity and for their curative action against $\mathrm{Tr}$. equiperdum by injection into normal and infected mice as described in the first paper of this series, special attention being paid, as before, to the question of oral administration.

Attention has again been devoted to three types of arsenic derivatives: (I) the arsinic acids in which the arsenic is in the pentavalent condition, (2) the arsenoderivatives, and (3) the arsenious oxides. In the two latter types of compounds, the arsenic is in the tervalent condition.

The simplest members of the series are structurally represented by the following formulæ :-

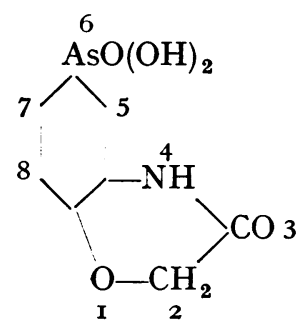

3-hydroxy I : 4-benzisoxazine-6-arsinic acid.

* Published in the British Journal of Venereal Diseases, January, 1927. I8I 
BRITISH JOURNAL OF VEREREAL DISEASES

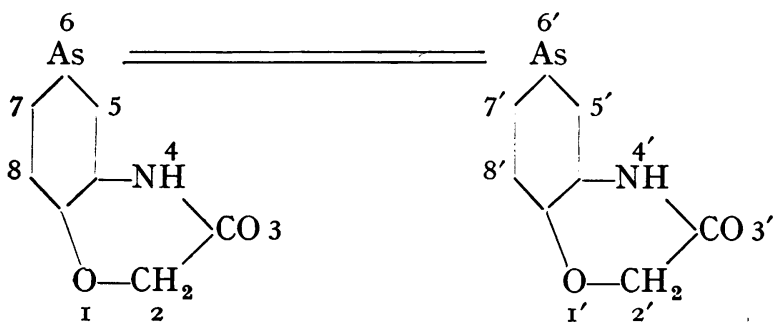

$3: 3^{\prime}$ dihydroxy $6: 6^{\prime}$ arseno $I: 4$-benzisoxazine.<smiles>O=C1COC2COCC(N2)S1</smiles>

3-hydroxy I : 4-benzisoxazine-6-arsenious oxide.

The following table includes the arsinic acid derivatives of the series which have been examined and the results obtained :

TABLE I

\begin{tabular}{|c|c|c|c|c|}
\hline Substance. & $\begin{array}{l}\text { Method of } \\
\text { administra- } \\
\text { tion. }\end{array}$ & $\begin{array}{c}\text { M.T.D. } \\
\text { mgs. per gm. }\end{array}$ & $\begin{array}{c}\text { M.C.D. } \\
\text { mgs. per gm. }\end{array}$ & Ratio $\frac{\text { M.T.D. }}{\text { M.C.D. }}$ \\
\hline $\begin{array}{l}\text { (I) 3-hydroxy I : 4-benzisox- } \\
\text { azine-6-arsinic acid. }\end{array}$ & $\begin{array}{l}\mathrm{I} \\
\mathrm{S} \\
\mathrm{O}\end{array}$ & $\begin{array}{l}0 \cdot 2 \\
0 \cdot 2 \\
3 \cdot 0\end{array}$ & $\begin{array}{l}0 \cdot 15 \\
0 \cdot 15 \\
0 \cdot 12\end{array}$ & $\begin{array}{r}I \cdot 3 \\
I \cdot 3 \\
25 \cdot 0\end{array}$ \\
\hline $\begin{array}{l}\text { (2) } 8 \text {-amino } 3 \text {-hydroxy I : 4- } \\
\text { benzisoxazine - } 6 \text { - arsinic } \\
\text { acid. }\end{array}$ & $\begin{array}{l}\mathrm{I} \\
\mathrm{S} \\
\mathrm{O}\end{array}$ & $\begin{array}{r}0 \cdot 8 \\
0 \cdot 8 \\
\mathrm{I} 4 \cdot 0\end{array}$ & $\begin{array}{l}>0.5 \\
>0.5 \\
>7.0\end{array}$ & $\begin{array}{l}<\mathrm{I} \cdot 4 \\
<\mathrm{I} \cdot 4 \\
<2 \cdot 0\end{array}$ \\
\hline $\begin{array}{l}\text { (3) 8-acetylamino-3-hydroxy I : } \\
4 \text { - benzisoxazine - } 6 \text { - arsi- } \\
\text { nic acid. }\end{array}$ & $\begin{array}{l}\mathrm{I} \\
\mathrm{S} \\
\mathrm{O}\end{array}$ & $\begin{array}{r}I \cdot 2 \\
I \cdot 2 \\
I 6 \cdot 0\end{array}$ & $\begin{array}{l}0 \cdot 3 \\
0 \cdot 3 \\
0 \cdot 2\end{array}$ & $\begin{array}{r}4 \cdot 0 \\
4 \cdot 0 \\
80^{\circ} \cdot 0\end{array}$ \\
\hline $\begin{array}{l}\text { (4) 7-acetylamino-3-hydroxy } \\
\text { I : 4-benzisoxazine-6-arsi- } \\
\text { nic acid. }\end{array}$ & $\mathrm{O}$ & $\mathrm{I} 4^{\circ} \mathrm{O}$ & $3 \cdot 0$ & $4 \cdot 7$ \\
\hline $\begin{array}{l}\text { (5) 8-glycylamino - 3-hydroxy } \\
\text { I : 4-benzisoxazine-6-arsi- } \\
\text { nic acid. }\end{array}$ & $\begin{array}{l}\mathrm{I} \\
\mathrm{S} \\
\mathrm{O}\end{array}$ & $\begin{array}{r}0.5 \\
0.5 \\
10 \cdot 0\end{array}$ & $\begin{array}{r}0 \cdot 3 \\
0 \cdot 3 \\
>6 \cdot 0\end{array}$ & $\begin{array}{r}\mathrm{I} \cdot 7 \\
\mathrm{I} \cdot 7 \\
<\mathrm{I} \cdot 6\end{array}$ \\
\hline
\end{tabular}


STUDIES IN ORGANIC ARSENIC DERIVATIVES

TABLE I-continued

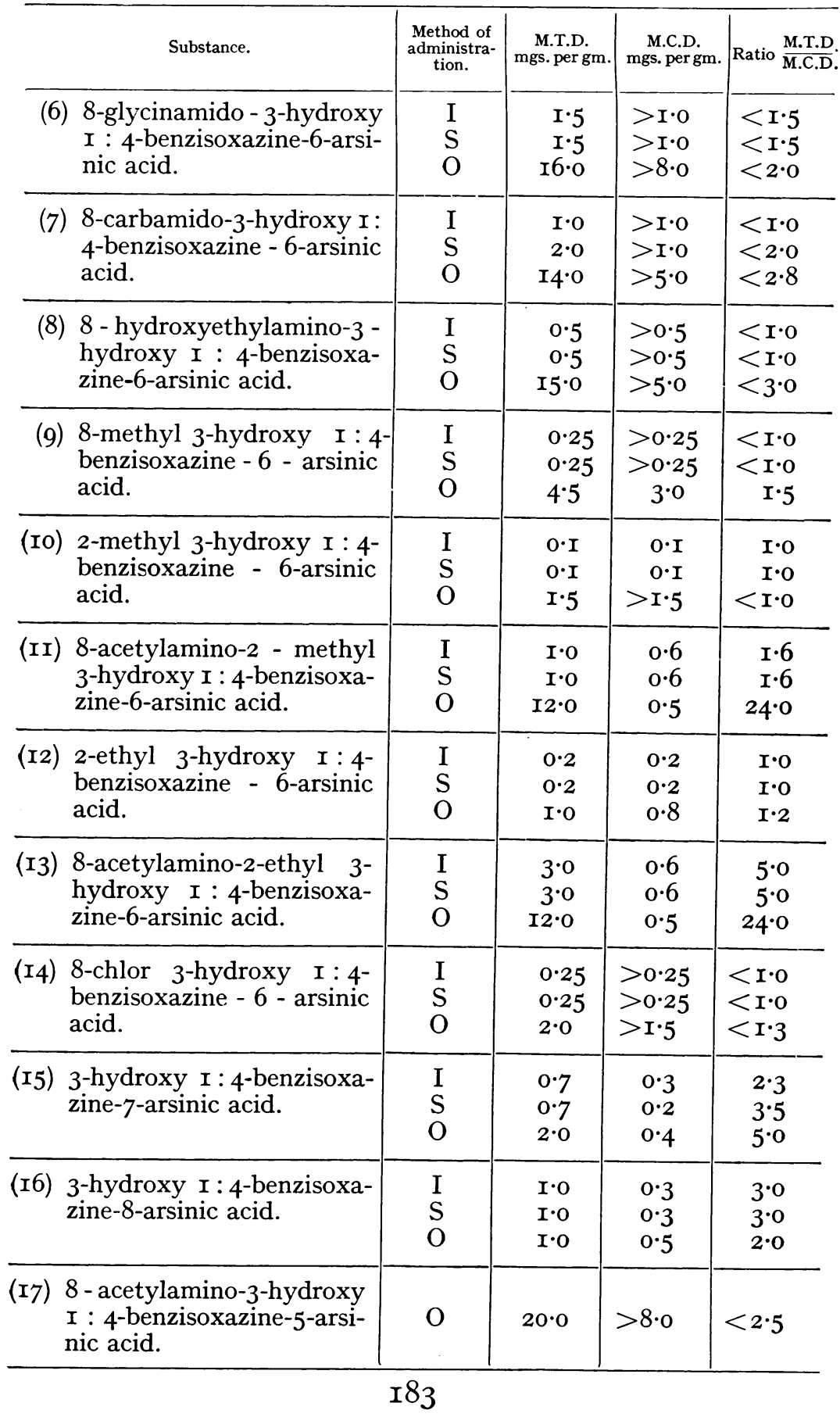


BRITISH JOURNAL OF VENEREAL DISEASES

TABLE I-continued

\begin{tabular}{|c|c|c|c|c|}
\hline Substance. & $\begin{array}{l}\text { Method of } \\
\text { administra- } \\
\text { tion. }\end{array}$ & $\begin{array}{c}\text { M.T.D. } \\
\text { mgs. per gm. }\end{array}$ & $\begin{array}{c}\text { M.C.D. } \\
\text { mgs. per gm. }\end{array}$ & Ratio $\frac{\text { M.T.D }}{\text { M.C.D }}$ \\
\hline $\begin{array}{l}\text { (I8) } 6 \text { - acetylamino-3-hydroxy } \\
\text { I : 4-benzisoxazine-8-arsi- } \\
\text { nic acid. }\end{array}$ & $\mathrm{O}$ & $4^{\circ} 0$ & $>3 \cdot 0$ & $<\mathrm{I} \cdot 3$ \\
\hline $\begin{array}{l}\text { (I9) } 2: 3 \text {-dihydro-I : 4-benzis- } \\
\text { oxazine-6-arsinic acid. }\end{array}$ & $\begin{array}{l}\mathrm{I} \\
\mathrm{S} \\
\mathrm{O}\end{array}$ & $\begin{array}{l}0.4 \\
0.4 \\
6.0\end{array}$ & $\begin{array}{l}O \cdot I 5 \\
O \cdot I 5 \\
O \cdot 2\end{array}$ & $\begin{array}{r}3 \cdot 0 \\
3 \cdot 0 \\
30^{\circ} 0\end{array}$ \\
\hline
\end{tabular}

$\mathrm{I}=$ intravenous injection.

$\mathrm{S}=$ subcutaneous injection.

$\mathrm{O}=$ oral administration.

The examination of this series of products yielded one or two points of interest. 3-hydroxy I : 4-benzisoxazine6-arsinic acid, which may be regarded as the parent compound of the series, was found to have a greater curative action than either Stovarsol or Tryparsamide with a therapeutic index comparable with both products. Any practical utility of this compound was, however, ruled out by the fact that experiments on animals showed it to possess very marked neuro-tropic properties, an observation which was borne out by the indications obtained from clinical trial in one or two cases of sleeping sickness (Chesterman). It is interesting to note that the isomeric 7 and 8-arsinic acids (Nos. I5 and 16 ) also showed neuro-tropic symptoms in marked degree, and that these effects persisted in the alkyl and halogen substituted derivatives (Nos. 9, I0, I2, I4), and in the reduced benzisoxazine derivative (I9), but were entirely eliminated by the introduction of amino- or substituted amino-groups, which also has the effect of very much reducing the general toxicity of the products. In this respect the introduction of an acetylamino group has a very marked effect, which is particularly noticeable on oral administration of such derivatives.

The comparatively low curative dose per os of 8-acetylamino-3-hydroxy I : 4-benzisoxazine - 6-arsinic acid (less than that of either Stovarsol or of Tryparsamide) suggested the possibility of its clinical application in one or other of the directions in which these products have been found to be of practical value. The low toxicity of 
the product was confirmed by further experiments carried out upon rabbits, which were found to tolerate doses of I $\mathrm{gm}$. per kilo by intravenous injection and up to 0.5 gm. per kilo by oral administration. Oral administration in cases of human primary syphilis showed that the product was extremely well tolerated, as much as I to I.5 gm. per day being given without any untoward results. Its curative action in such cases was, however, negligible. The effect of the compound in the later stages of syphilis is at present under investigation. The product, to which has been given the name "Parosan," has also been tried in disseminated sclerosis with encouraging results, but it is as yet too early to estimate its real value in such cases. The non-toxicity of Parosan on oral administration is, however, fully established, and thus is added another to the list of organic arsenic derivatives capable of administration by this method. The compound has also been tried in a few cases of yaws, in which disease it appears to be only feebly active, and also in sleeping sickness. Preliminary reports suggest that its effects in the treatment of the latter disease on oral administration are not pronounced, but that the product appears to be trypanocidal when injected intravenously as the sodium salt. The suggested parallelism between Parosan and Tryparsamide appears, therefore, in some degree to hold. The main advantage of the former, other things being equal, would appear to be in the comparative freedom from the possibility of the production of amblyopia or other neuro-tropic symptoms. Of the remaining members of the series, none of them appeared to possess such characteristics as would warrant clinical trial in any direction. It is, however, by no means certain that fuller investigation of such products in one field or another might yield results of real interest and practical value.

Table II summarises the results obtained by the examination of a number of arseno-benzisoxazines, i.e., compounds of the Salvarsan type, but containing the benzisoxazine ring in one or both halves of the molecule.

These compounds, as well as the oxides enumerated below, are for the most part of very little practical interest, since they are insoluble in water and do not form salts, except in certain cases with a large excess of caustic alkali. They do, however, present some points of interest 
BRITISH JOURNAL OF VENEREAL DISEASES

Arseno Bases

TABLE II

\begin{tabular}{|c|c|c|c|c|}
\hline Substance. & $\begin{array}{l}\text { Method of } \\
\text { administra- } \\
\text { tion. }\end{array}$ & $\begin{array}{c}\text { M.T.D. } \\
\text { mgs. per gm. }\end{array}$ & $\begin{array}{c}\text { M.C.D. } \\
\text { mgs. per gm. }\end{array}$ & Ratio $\frac{\text { M.T.D. }}{\text { M.C.D. }}$ \\
\hline 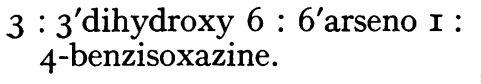 & $\mathrm{O}$ & $I \cdot O$ & 0.05 & $20 \cdot 0$ \\
\hline $\begin{array}{l}8: 8^{\prime} \text { diamino-3 : } 3^{\prime} \text { dihydroxy- } \\
6 \text { : 6'arseno I : } 4 \text { ben- } \\
\text { zisoxazine. }\end{array}$ & $\mathrm{O}$ & $20 \cdot 0$ & $8 \cdot 0$ & $2 \cdot 5$ \\
\hline $\begin{array}{l}\text { 5-acetylamino-2 : } 3^{\prime} \text { dihydroxy } \\
\text { I : 6'arsenobenzene I' } \text { I }^{\prime} \text { - } \\
\text { benzisoxazine. }\end{array}$ & $\mathrm{O}$ & $2 \cdot 0$ & $0 \cdot 04$ & $50 \cdot 0$ \\
\hline $\begin{array}{l}8: 8^{\prime} \text { diacetylamino-3 : } 3^{\prime} \text { di- } \\
\text { hydroxy } 6: 6^{\prime} \text { arseno I }: 4^{-} \\
\text {benzisoxazine. }\end{array}$ & $\begin{array}{l}\mathrm{I} \\
\mathrm{S} \\
\mathrm{O}\end{array}$ & $\begin{array}{l}0 \cdot 025 \\
0 \cdot 60 \\
18 \cdot 0\end{array}$ & $\begin{array}{l}0 \cdot 002 \\
0 \cdot 01 \\
0 \cdot 08\end{array}$ & $\begin{array}{r}12 \cdot 5 \\
60^{\circ} 0 \\
225^{\circ} 0\end{array}$ \\
\hline $\begin{array}{l}6: 6^{\prime} \text { diacetylamino-3 : } 3^{\prime} \text { di- } \\
\text { hydroxy } 8: 8^{\prime} \text { arseno } \text { I: } 4^{-} \\
\text {benzisoxazine. }\end{array}$ & $\mathrm{O}$ & $\mathrm{I} 2 \cdot 0$ & $>4^{\circ} 0$ & $<3 \cdot 0$ \\
\hline $\begin{array}{l}5: 8^{\prime} \text { diacetylamino-2 : } 3^{\prime} \text { di- } \\
\text { hydroxy } 6: 6^{\prime} \text { arsenobenzene } \\
I^{\prime}: 4^{\prime} \text {-benzisoxazine. }\end{array}$ & $\begin{array}{l}\mathrm{I} \\
\mathrm{S} \\
\mathrm{O}\end{array}$ & $\begin{array}{l}0.05 \\
0.05 \\
25 \cdot 0\end{array}$ & $\begin{array}{l}0.005 \\
0.005 \\
0.2\end{array}$ & $\begin{array}{r}I 0 \cdot 0 \\
10 \cdot 0 \\
\text { I } 25.0\end{array}$ \\
\hline $\begin{array}{l}3: 8^{\prime} \text { diacetylamino- } 3^{\prime}: 4 \text { di- } \\
\text { hydroxy I : 6'arsenobenzene } \\
\text { I' }^{\prime}: 4^{\prime} \text {-benzisoxazine. }\end{array}$ & $\mathrm{O}$ & $20 \cdot 0$ & $4^{\cdot 0}$ & $5^{\circ} 0$ \\
\hline $\begin{array}{l}3: 5: 8^{\prime} \text { triacetylamino- } 3^{\prime}: 4 \text { di- } \\
\text { hydroxy I : } 6^{\prime} \text { arsenobenzene } \\
\mathrm{I}^{\prime}: 4^{\prime} \text {-benzisoxazine. }\end{array}$ & $\mathrm{O}$ & $20 \cdot 0$ & 0.8 & $25^{\circ} 0$ \\
\hline $\begin{array}{l}6: 6 \text { 'arseno dihydro-I : 4-ben- } \\
\text { zisoxazine. }\end{array}$ & $\mathrm{O}$ & $2 \cdot 0$ & $0 \cdot 2$ & IO $\cdot 0$ \\
\hline
\end{tabular}

if their general therapeutic activity is compared with that of the corresponding parent acids.

Thus an acid having in general little or no therapeutic ratio gives on reduction a base which is likewise possessed of little or no ratio, while the more effective acids give rise to bases with similarly high ratios. This is particularly marked with the oral ratios, which are in general much higher than those obtained on injection. 
STUDIES IN ORGANIC ARSENIC DERIVATIVES

TABLE III

\begin{tabular}{|c|c|c|c|c|}
\hline Substance. & $\begin{array}{c}\text { Method of } \\
\text { administra- } \\
\text { tion. }\end{array}$ & $\begin{array}{c}\text { M.T.D. } \\
\text { mgs. per gm. }\end{array}$ & $\begin{array}{c}\text { M.C.D. } \\
\text { mgs. per gm. }\end{array}$ & Ratio $\frac{\text { M.T.D. }}{\text { M.C.D. }}$ \\
\hline $\begin{array}{l}\text { 3-hydroxy I : 4-benzisoxazine- } \\
\text { 6-arsenious oxide. }\end{array}$ & $\begin{array}{l}\mathrm{I} \\
\mathrm{S} \\
\mathrm{O}\end{array}$ & $\begin{array}{l}0 \cdot 0 I \\
0 \cdot 0 I \\
I \cdot 00\end{array}$ & $\begin{array}{l}0 \cdot 0 I \\
0 \cdot 0 I \\
0 \cdot 04\end{array}$ & $\begin{array}{r}I \cdot O \\
I \cdot O \\
25 \cdot 0\end{array}$ \\
\hline $\begin{array}{l}\text { 8-acetylamino- 3-hydroxy } \\
\text { I : 4-benzisoxazine-6-arse- } \\
\text { nious oxide. }\end{array}$ & $\begin{array}{l}\mathrm{I} \\
\mathrm{S} \\
\mathrm{O}\end{array}$ & $\begin{array}{r}0 \cdot 03 \\
0 \cdot 03 \\
25 \cdot 00\end{array}$ & $\begin{array}{l}0 \cdot 0005 \\
0 \cdot 0005 \\
0 \cdot 02\end{array}$ & $\begin{array}{r}60 \cdot 0 \\
60 \cdot 0 \\
I 250 \cdot 0\end{array}$ \\
\hline $\begin{array}{l}2 \cdot: \text { 3-dihydro I : 4-benzisoxa- } \\
\text { zine-6-arsenious oxide. }\end{array}$ & $\mathrm{O}$ & $0 \cdot 30$ & 0.03 & IO.O \\
\hline
\end{tabular}

Furthermore, the combination of two structurally dissimilar acids to produce asymmetric arseno derivatives generally results in the production of a base in which the therapeutic activity is a mean of the bases which would normally be produced by the reduction of the acids separately. This is in some degree what one might expect from the theory of the action of these arsenical derivatives which has been put forward by Voegtlin and his coworkers, in which the action of the acids and the arseno bases is generally held to be dependent on their reduction to the corresponding oxides. The investigation of the simple arsinic acids thus affords suggestions for the synthesis of more complex arseno compounds with desirable properties ; and work along these lines, it is hoped, may be productive of compounds of practical value, since there undoubtedly appears to be a real need for a product of higher therapeutic efficiency than Novarsenobenzene, which at the same time shall retain the very obvious advantages of this product over Arsenobenzene (Salvarsan) itself.

It may not be altogether out of place to mention another direction in which some of these arsenical products may prove to be of interest. The observations of Marchoux and others on Stovarsol showed it to have a specific action on Plasmodium vivax of benign tertiary malaria. The work of Major Sinton and his collaborators confirmed and amplified these results in that Stovarsol was found to be a useful adjunct to Quinine treatment in cases of chronic benign tertiary malaria. The results obtained with 


\section{BRITISH JOURNAL OF VENEREAL DISEASES}

Stovarsol led to the suggestion that the isomeric 2-hydroxy 5-acetylamino-phenyl-arsinic acid (Troposan) should be tried in place of the former compound. This has been done and a still greater amount of success achieved. The product is less toxic than Stovarsol, and the relapse rate considerably less than with either Quinine alone or with Quinine-Stovarsol. The full report of this work will shortly be published by Major Sinton and his colleagues. Work along similar lines with other organic derivatives of arsenic is also in progress from the experimental side in collaboration with Dr. Macfie, of the London School of Tropical Medicine.

\section{REFERENCES}

A. J. Ewins and J. G. Everetr. This Journal, Jan., I927, p. I.

C. C. Chesterman and K. W. Todd. Trans. Roy. Soc. Trop. Med. and Hygiene, Nov., I927, Vol. XXI., No. 3, p. 227.

Voegtlin and Smith. Journ. Pharmacol. and Exp. Therap., I921, XVI., I99.

E. MarchouX. Ann. Inst. Pasteur, XXXIX., 3, p. I47. 